\title{
p53 family genes: structural comparison, expression and mutation
}

\author{
S Ikawa ${ }^{1}$, A Nakagawara ${ }^{2}$ and Y Ikawa*,3 \\ 1 Institute of Development, Aging and Cancer, Tohoku University, Sendai 980- \\ 8575, Japan \\ ${ }^{2}$ Chiba Cancer Research Institute, Chiba 260-0801, Japan \\ ${ }^{3}$ Human Gene Sciences Center, Tokyo Medical and Dental University, Tokyo \\ 113-8510, Japan \\ * Corresponding author: Y Ikawa, Tokyo Medical and Dental University, 1-5-45 \\ Yushima, Bunkyo-ku, Tokyo 113-8519, Japan. Tel: +81-3-5803-5159; \\ Fax: +81-3-3814-7172; E-mail: y.ikawa.mbch@med.tmd.ac.jp
}

Received 19.10.99; accepted 28.10.99

Edited by R Knight

\begin{abstract}
The p53-related genes, $\mathrm{p} 51 / \mathrm{p} 63$ and $\mathrm{p} 73$, have been isolated respectively from CDNA libraries of skeletal muscle and the brain, and their structural features and biological functions have been compared. High expression of $\mathrm{p} 51 \mathrm{~A}(\mathrm{TAp} 63 \gamma)$ in the skeletal muscle tissue drove us to investigate a differentiationinducible myoblastic cell line which showed increased p51A expression after differentiation induction. Tissue-specific expression was further confirmed by reverse transcriptasepolymerase chain reaction (RT-PCR) using primers specific for $\triangle \mathrm{N}$ (TA-domain lacking p51), p51A, and p51B expression. p51A alone induced erythrodifferentiation when expressed in the erythroleukemia line (Tg-gp55-1-2-3) expressing a temperature-sensitive mutant of $p 53$, and induced remarkable apoptosis when wild-type $p 53$ expression was induced by the temperature shift to $32^{\circ} \mathrm{C}$. Human p51A and p53 were introduced exogenously into the above erythroleukemia cells, and although their expression was rather low, both p51A and p53 proteins were induced by DNA-damaging treatment with UV and ActinomycinD. However, the protein-protein interactions analyzed by a yeast two-hybrid assay between $\mathrm{p} 51$ and p53, between p51 and p73, and between p51 and oncoproteins showed that $\mathrm{p} 51$ is functionally rather distant from $\mathrm{p} 53$. Extensive mutation analysis of p51/p63 in human tumors revealed only four mutations in 80 non-small cell lung carcinomas; two adenocarcinoma cases possessing Glu31His mutations in the transactivation domain (TA) domain, suggesting that $\mathrm{p51/p63}$ is not a Knudson type tumor suppressor gene. Mutation and loss of heterozygosity ( $\mathrm{LOH})$ of $p 73$, deregulated expression of $p 73$ and loss of imprinting of p73 are also discussed.
\end{abstract}

Keywords: p53 family genes; p51/p63; p73; splice variants; tissuespecific expression; mutation
Abbreviations: A tail, OD of p51A; B tail, OD of p51B; C-terminal, carboxy-terminal; CPRG, chlorophenol red-b-D-galactopyranoside; DB/DBD, DNA-binding domain; $\mathrm{LOH}$, loss of heterozygosity; $\mathrm{LOI}$, loss of imprinting; OD, oligomerization domain; RT-PCR, reverse transcriptase-polymerase chain reaction; TA p63/p51, TApossessing p63/p51; TA/TAD, transactivation domain; UV, ultraviolet light

\section{Isolation and structural comparison}

Isolation of human p51, another p53-related gene

Isolation of the first p53-related gene, $p 73,{ }^{1}$ encouraged us to attempt to isolate further p53-related genes.

Using the interspecifically conserved region of $\mathrm{p} 53$, we made degenerate primers for PCR (Figure 1) to isolate human p53-related genes. We first employed outside primers $A$ and $D$, and then nested primers $B$ and $C$ to isolate further closely p53-related DNA fragments from tissue-specific cDNA libraries. With this strategy, we successfully cloned a second p53-related gene from a skeletal muscle cDNA library, which we named p51A since this cDNA codes for a protein with the estimated molecular weight of $51 \mathrm{kDa}$. We also cloned a larger splice variant of the gene, designated p51B (estimated molecular weight $72 \mathrm{kDa}){ }^{2}$ p51B was previously isolated from rat tissue and was designated as 'ket' gene. ${ }^{3}$ The structural aspects of these genes and some of their biological characteristics have been described by us previously. $^{2}$ This p53-related p51 gene has also been cloned by other groups and variously designated as $\mathrm{p} 40^{4}$, $\mathrm{p} 63^{5}$ and $\mathrm{p} 73 \mathrm{~L}^{6}$.

\section{Structural comparison of p53-related genes}

We also cloned cDNA's of the $\mathrm{p} 73 \alpha$ and $\mathrm{p} 73 \beta$ genes from a cDNA library of human brain. ${ }^{2}$ The homology between the $\mathrm{p} 53$, p51A, and $\mathrm{p} 73 \beta$ products at a protein level is shown in Figure 2.

In $\mathrm{p} 73$, smaller splice variants, $\mathrm{p} 73 \gamma$ and $\mathrm{p} 73 \delta$ have also been found: ${ }^{7}$ in p51/TAp63, several smaller splice variants have also been characterized. One of these, p51C $(\delta)$, was observed in several tissues including uterus, thymus, placenta, mammary gland and fetal lung. ${ }^{8}$

The fourth splice variant was identified in the same way as p73, and the p51 splice variants so far characterized are $\mathrm{p} 51 \alpha(=\mathrm{p} 51 \mathrm{~B}), \mathrm{p} 51 \beta, \mathrm{p} 51 \delta(=\mathrm{p} 51 \mathrm{~A})$, and $\mathrm{p} 51 \gamma$, as previously shown in $\mathrm{p} 63$ and p51 splice variants. ${ }^{8}$ Amino-terminally deleted p51 variants have also been described, ${ }^{5,8}$ and they are expressed both in some normal and neoplastic tissues, ${ }^{8}$ but their C-terminal tails including the oligomerization domain have yet to be analyzed in detail. 


\section{Expression and biological function of p51/TAp63}

\section{Tissue-specific expression of p51/TAp63}

We have previously shown that p51A/TAp63 $\gamma$ and p51B/ TAp63 $\alpha$ are expressed in a tissue-specific manner by

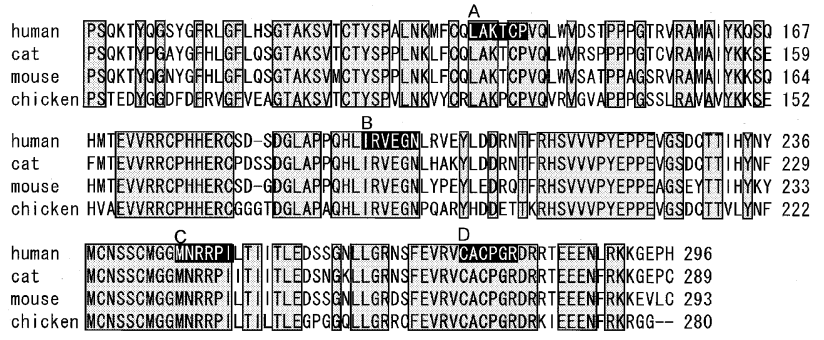

Figure 1 Interspecifically conserved regions of p53, A, B, C, D were used to make degenerate primers to isolate p53-related DNA fragments

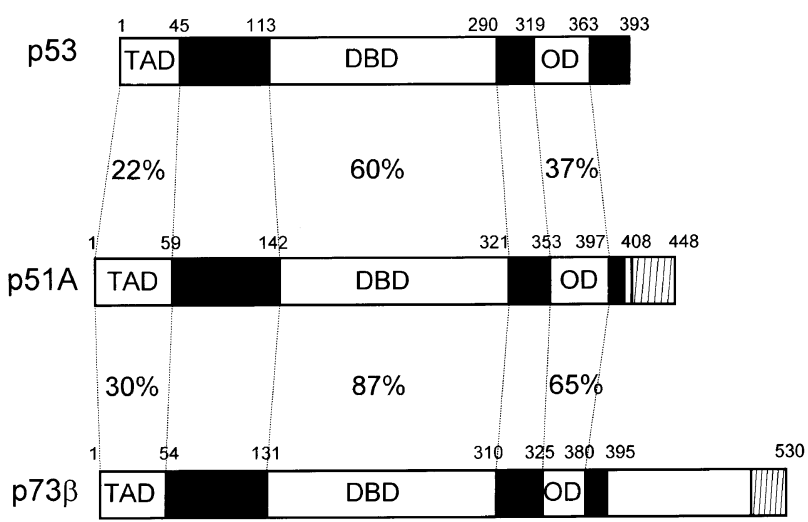

Figure 2 Structural comparison of p53 family proteins. TAD: Transcriptional activation domain; DBD: DNA-binding domain; OD: Oligomerization domain

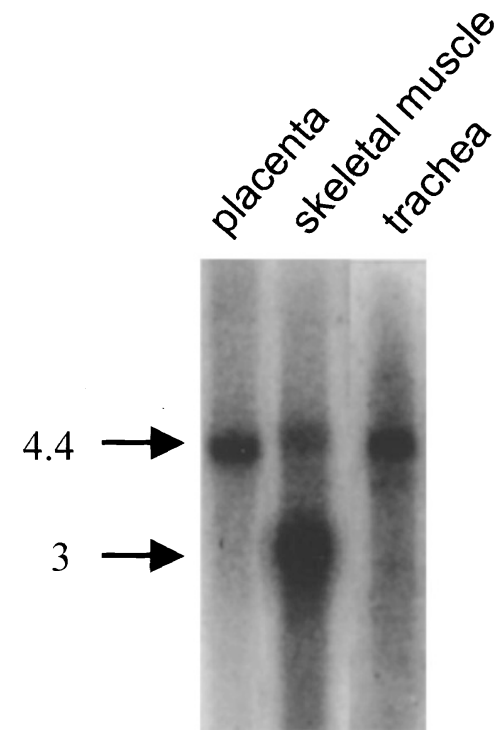

Figure 3 Northern blotting of p51 mRNAs. The skeletal muscle p51B transcript is slightly larger than those of other tissues, possibly suggesting another splice-variant
Northern blotting analysis; p51B/TAp63 $\alpha$ is highly expressed in the placenta, mammary gland, salivary gland and prostate (Figure 3). Yang et al. also reported that the p63 protein is expressed in the epithelial linings of urogenital organs. ${ }^{5}$

Recent gene knock-out studies have shown that p51/ TAp63 is essential for skin formation and in the generation of apical ectodermal ridges to induce development of the extremities. ${ }^{9,10}$

\section{p51/TAp63 may be involved in mesenchymal differentiation}

Since p51A, a short form of the two major splice-variants of p51, is predominantly expressed in skeletal muscle (Figure $3)$, we investigated p51 expression in the differentiationinducible myoblastic cell line, $\mathrm{C} 2 \mathrm{C} 12$ by Northern blotting. We observed a gradual increase of both p51A and p51B mRNA's in C2C12 cells 1-2 days after decreasing the horse serum concentration down to $2 \%$ (Figure 4 ) (unpublished observation).

We synthesized PCR primers for the detection of $\Delta \mathrm{N} p 51$; p51A (A tail) and p51B (B tail), and carried out RT - PCR to analyze their respective expression (Figure 5). Some tissues showed expression of all three variants (such as bladder and skin, Figure 6); others showed $\Delta \mathrm{N}$ p51 and p51A expression; skeletal muscle showed p51A and p51B and heart only p51A. p51 was not expressed in GI tract and spleen (M. Osada et al. unpublished observation). These tissues were taken from 10 weeks old non-pregnant female mice (Figure 6).

\section{Potentiating p53 transactivation capacity by exchange of p51A and p51B tails}

The p51/TAp63 gene encodes two major splicing variants, p51A and p51B, which differ in their carboxyl-terminal structures. However, p51A shows a moderate level of transcription, while p51B shows extremely low level expression. To clarify the reason for this difference, we made chimeric gene constructs expressing fusion proteins of p53-
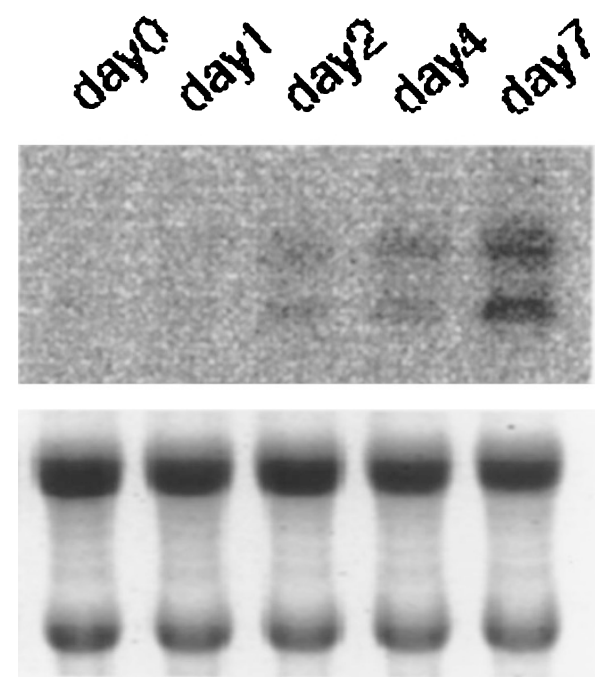

Figure 4 Northern blotting of $\mathrm{p} 51 \mathrm{~A}$ and $\mathrm{p} 51 \mathrm{~B}$ transcripts in differentiationinduced $\mathrm{C} 2 \mathrm{C} 12$ cells 


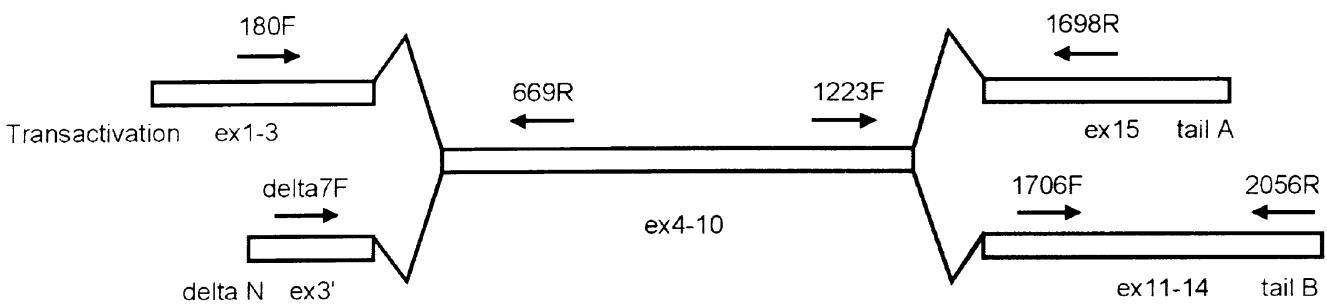

Figure 5 Design of PCR primers for RT - PCR detection of $\triangle \mathrm{Np} 51$, p51A, and p51B transcripts

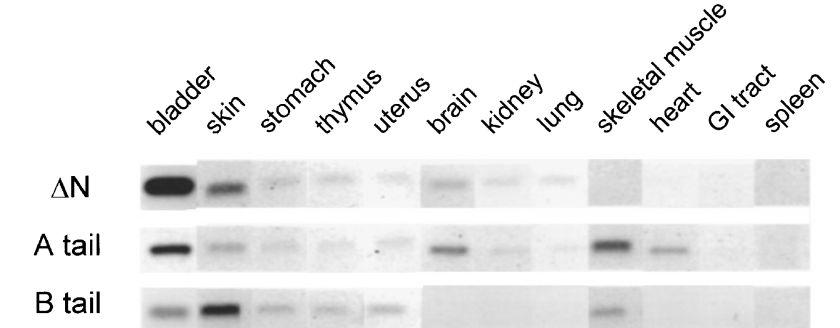

Figure 6 RT - PCR analysis of p51 transcripts in various mouse organs using primers shown in Figure 5

p51A and p53-p51B, having an N-terminus of p53 and a Cterminus of $\mathrm{p} 51 \mathrm{~A}$ or $\mathrm{p} 51 \mathrm{~B}$, respectively. In a BAX promoterluciferase assay using p53-deficient SAOS-2 cells, they exhibited up to 30 -fold stronger transactivation potential than p53 and p51A themselves, suggesting that the C-terminus of p51B does not simply serve as a transcriptional repressor. ${ }^{7}$ We obtained similar results with p21waf1 and MDM-2 promoter-reporter plasmids (Figure 7). These chimeras are valuable tools for gene therapy. S Ikawa's group has actually constructed all possible chimeric genes using the respective TA, DNA binding and oligomerization domains of the three p53 family genes. These chimeric genes also overcome the problems of dominant-negative mutant p53 genes. More precise chimeric molecules may further dissect the functional domains of the p53 family proteins.

\section{Human p51A can induce erythrodifferentiation in Friend erythroleukemia cells}

An erythroleukemia cell line was established from a transgenic mouse with Friend spleen focus-forming virus env-related gp55 gene. ${ }^{11,12}$ This line possesses a monoallelically expressed temperature-sensitive mutant p53 gene. Some preliminary data was briefly described in our previous paper. ${ }^{2}$ Further studies revealed that p51A alone could induce erythrodifferentiation by DAF and TER 119 staining (Figure 8).

\section{How are p51/TAp63 and p73 related to and distinct from p53}

\section{Oncoprotein-binding of p51 and p73}

In a preliminary analysis to compare the binding capacity of p51A with that of p53, we employed a yeast two-hybrid assay using MDM2 and SV40 Large T proteins to be targeted by TAp53 family proteins and $\Delta \mathrm{N}$-p53 family proteins. Using the Y187 yeast strain, and applying $\beta$-gal colony-lift filter and CPRG (chlorophenol red- $\beta$-D-Galactopyranoside) assays we measured protein-protein binding. p51A and p51B bound to each other, but not to other p53 family proteins, SV40LT and MDM2, while p73 bound MDM2 more tightly than p53 (Table 1). (O Kojima et al. unpublished observation).

\section{p51A responds to DNA-damaging treatment}

Human p51A and human p53 were exogenously introduced into 1-2-3 cells as described in the previous section, and these cells responded almost equally to DNA-damaging treatments (UV, and Actinomycin D) with low induction of p51A and p53 transcripts but more pronounced $\mathrm{p} 51 \mathrm{~A}$ and $\mathrm{p} 53$ protein induction to upregulate the p21 waf- 1 gene equally immediately after the treatment (Katoh I. et al. presented at $58^{\text {th }}$ Japanese Cancer Association meeting in Hiroshima on October $\left.1^{\text {st }}, 1998\right)$.

These data suggest that p51 and p73 show distinct tissue-specific expression and show quite different biological responses, and it would be of great interest to study phylogenetically how p53 evolved for protection against DNA damage or for elimination of abnormal cells.

\section{Loss of heterozygosity, expression and mutation of p73 and p51/p63 in human cancers}

The role of $p 73$ and p51/p63 in carcinogenesis and/or cancer progression remains ambiguous at the present time. However, it is important to know whether p73 or p51/p63 are also tumor suppressor genes since p53 is not mutated in about a half of human cancers. Here we overview the data accumulated during the last 2 years and reconsider their biological and clinical role in cancer.

\section{Loss of heterozygosity of the p73 gene mapped to $1 \mathrm{p} 36.3$}

The $\mathrm{p} 73$ gene has been mapped to $1 \mathrm{p} 36.3$ which is frequently deleted in many cancers including neuroblastoma, colorectal cancer and breast cancer. ${ }^{1}$ For p73 to have a role as a tumor suppressor gene, it is crucial for p73 to be mapped within the commonly deleted region of these cancers. Two groups have performed fine mapping of the p73 gene, and showed that it was localized at D1S468 between D1Z2 and D1S47 which 


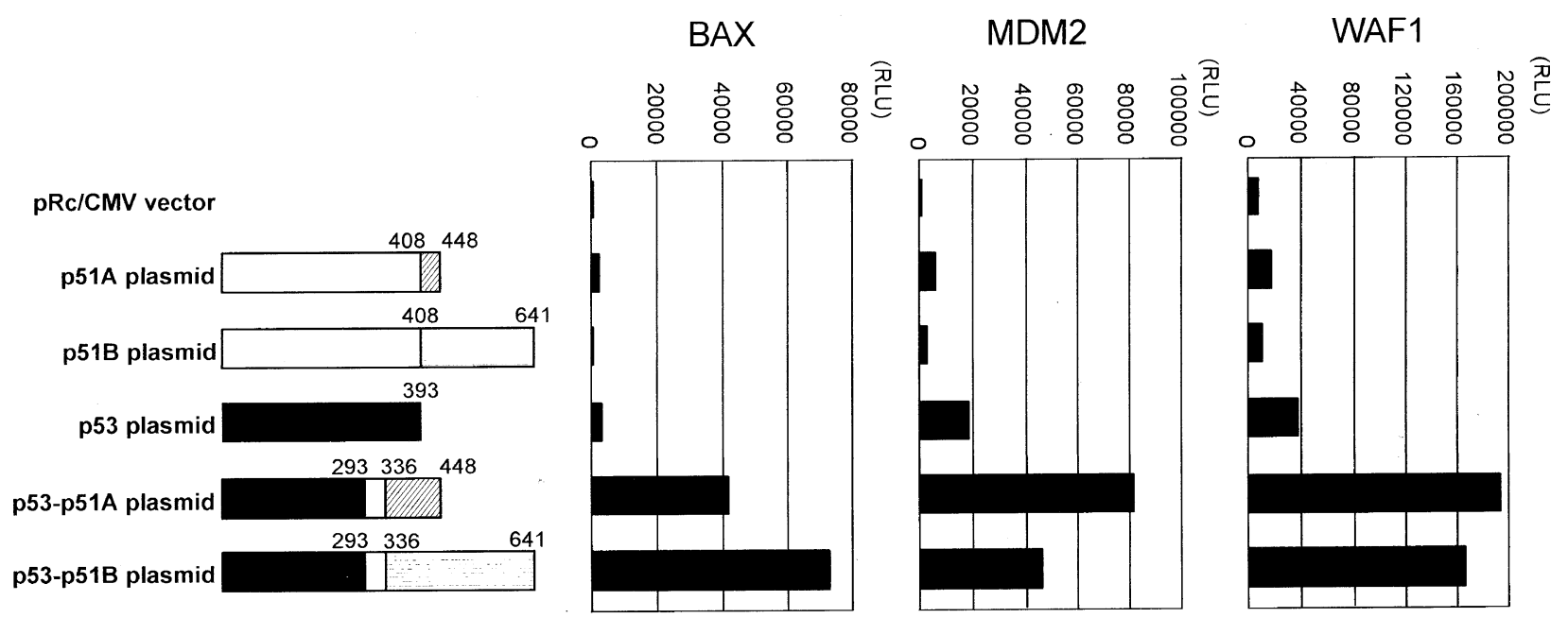

Figure 7 Transactivation of BAX, MDM2, and WAF1 genes by p53-p51 chimeric proteins

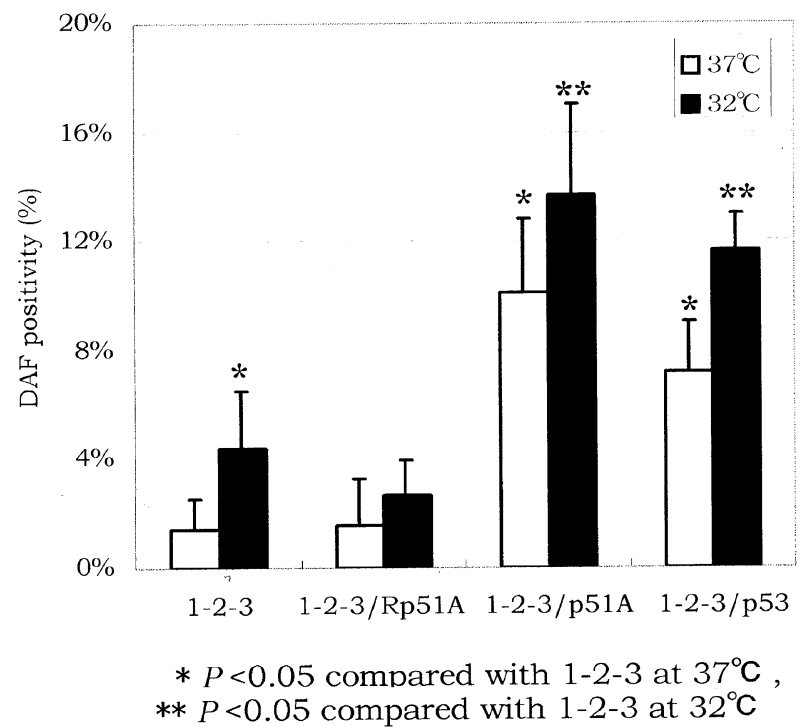

Figure 8 Hemoglobin production in 1-2-3 cells transfected with p51A. Cells were analyzed $24 \mathrm{~h}$ after the temperature shift. DAF (2,7-diaminofluorene) is non-genotoxic Benzidine-like chemical. Rp51A is the anti-sense or reversed p51A sequence

spanned less than $6 \mathrm{Mb} .^{13,14}$ This suggested that $\mathrm{p} 73$ was still within the smallest region of overlap (SRO) in neuroblastoma, colorectal cancer and breast cancer. Ichimiya et al. ${ }^{15}$ also showed that p73 was localized at the border of the SRO at 1 p36.3 in neuroblastoma. The frequency of the p73 loss of heterozygosity (LOH) was variable: high in neuroblastoma, ${ }^{15,16}$ lung cancer (mostly non-small cell lung cancers ${ }^{17}$ and Yamamoto et al. unpublished data), gastric cancer ${ }^{18}$ and ovarian cancer, ${ }^{19}$ and low in esophageal cancer ${ }^{20}$ and prostate cancer $^{21}$ (Table 2). The frequency of $\mathrm{LOH}$ in the region including the p73 gene was high in lung ${ }^{17}$ and ovarian $^{19}$ cancers. This raised the possibility that $p 73$ was a candidate suppressor gene of some, if not all, human cancers.

\section{Expression of p73 in cancers and normal tissues}

To date, six p73 isoforms $(\alpha \beta \gamma \gamma \delta \varepsilon \zeta)$ generated by alternative splicing have been reported. ${ }^{1,7,22}$ Both $p 73 \alpha$ and p73 $\beta$ are ubiquitously expressed in brain, kidney, placenta, colon, heart, liver, spleen, and skeletal muscle at low levels. $\mathrm{p} 73 \gamma$ and $\mathrm{p} 73 \delta$ are also expressed in many normal tissues, but the expression pattern is different. ${ }^{22}$ Normal human lymphocytes lack $\mathrm{p} 73 \beta$ and express only the $\mathrm{p} 73 \alpha$, $\mathrm{p} 73 \gamma$ and $\mathrm{p} 73 \delta$ forms, whereas normal human keratinocytes express $\mathrm{p} 73 \alpha, \mathrm{p} 73 \beta$, and $\mathrm{p} 73 \gamma$ but not $\mathrm{p} 73 \delta$. In general, $\mathrm{p} 73 \alpha$ is predominantly expressed in most normal tissues and cell lines. The levels of p73 expression are so low that it is often difficult to detect the transcripts by Northern blot analysis.

Primary cancers also express p73 whose predominant form is $p 73 \alpha$. The levels of $p 73$ expression among cancers are variable and generally low. The expression levels in neuroblastoma are lower than in other cancers. ${ }^{11,15}$ It is unclear whether normal sympathetic neurons or adrenal medullary cells, from which neuroblastoma is derived, express p73 or not, because of the difficulty in obtaining the corresponding normal tissue. However, our preliminary data suggested that p73 was not detectable even by RT$\mathrm{PCR}$ in the normal adrenal tissue of an infant ( $A$ Nakagawara, unpublished data).

The relative expression levels of p73 in cancers compared with those in normal tissues are very important to understand the role of the gene in carcinogenesis. Takahashi et al. ${ }^{21}$ first showed that expression of p73 was higher in a prostate cancer than in corresponding normal tissue. Similar observations have subsequently been reported by other groups in several cancers including neuroblastoma, ${ }^{23}$ lung cancer, ${ }^{24}$ colorectal cancer, ${ }^{25}$ breast cancer, ${ }^{26}$ bladder cancer, ${ }^{27}$ and cholangiocarcinoma of the liver, ${ }^{28}$ as shown in Table 2 . The expression of p73 may be regulated in a tissue specific manner. ${ }^{17}$ There may be several reasons why $p 73$ is expressed in 
cancerous tissues at higher levels than in their normal counterparts, including activation of promoter function or loss of imprinting.

\section{Imprinting and/or loss of imprinting of p73 in cancer?}

The evidence for imprinting at the distal region of chromosome $1 p$ in cancer first emerged from the genetic study of neuroblastoma. The frequent allelic loss of 1 p36 was found to be imprinted in sporadic neuroblastomas. ${ }^{29,30}$ In the tumors with a single copy of MYCN, the deleted 1 p36 alleles were preferentially of maternal origin, and the commonly deleted region was mapped to 1p36.2-pter. On the other hand, in tumors with MYCN amplification, the large $1 p$ deletions extending from the telomere to at least 1p35-p36.1 were of random parental origin. If the observations by Caron et al. ${ }^{29,30}$ are confirmed, maternal p73 is lost in about $70 \%$ of neuroblastomas with $1 p$ deletion. The p73 gene is localized in such an imprinting region at the distal end of $1 p$.
Monoallelic expression of p73 was first reported by Kaghad et al. ${ }^{1}$ Since mutation of p73 in cancers is rare, epigenetic regulation of p73 would provide alternative evidence for its role as a tumor suppressor gene. However, the current status of the allelic expression of the p73 gene is confusing as shown in Table 2. For example, Mai et al. demonstrated loss of imprinting (LOI) in lung cancer ${ }^{24}$ and renal cell carcinoma. ${ }^{31}$ They also reported the presence of allele switching in two of 12 primary renal cell carcinomas. ${ }^{32}$ In contrast, Nomoto et al. ${ }^{17}$ found biallelic expression of p73 in 25 out of 26 lung cancers, suggesting that monoallelic expression of p73 was rare and would be variable between individuals and different tissues. Thus, information about the imprinting of p73 in cancers is still limited and confusing. It is important to know the degree of LOI in human cancers. If LOI of the p73 gene is a common event, the gene may function to enhance tumor cell growth like an oncogene. We also need to know in which normal tissues p73 is frequently imprinted, since the frequency of $1 \mathrm{p} 36 \mathrm{LOH}$ varies between human cancers of different tissue origin (Table 2).

Table 1 Interaction between p53 family protein and p53-binding oncoproteins

\begin{tabular}{|c|c|c|c|c|c|}
\hline & SV40 Large T antigen & MDM2 & p53 & $\begin{array}{l}\text { p51A } \\
\text { p51B }\end{array}$ & $\begin{array}{l}\text { p73 } \\
\text { p73 }\end{array}$ \\
\hline p53 & +++ & + & & & \\
\hline p51A, p51B & - & - & - & + & \pm \\
\hline $\mathrm{p} 73 \alpha, \mathrm{p} 73 \beta$ & - & ++ & - & - & - \\
\hline
\end{tabular}

Table 2 Loss of heterozygosity, mutation and expression of the p73 gene in primary cancers

\begin{tabular}{|c|c|c|c|c|c|}
\hline Cancer & Reference & p73 LOHa & Mutation & Expression & Imprinting \\
\hline Neuroblastoma & Kovalev et al. ${ }^{23}$ & & $0 / 16$ & $\mathrm{~T}>\mathrm{N}^{\mathrm{b}}$ & biallelic $(5 / 6)$ \\
\hline Neuroblastoma & Ichiyama et al. ${ }^{15}$ & $34 \%(20 / 59)$ & $\begin{aligned} & 2 / 140(\mathrm{P} 405 \mathrm{R}) \\
&(\mathrm{P} 425 \mathrm{~L})\end{aligned}$ & & \\
\hline Neuroblastoma & Ejesker et al. ${ }^{16}$ & $33 \%(10 / 30)$ & $0 / 30$ & & \\
\hline Neuroblastoma & Han et al. ${ }^{35}$ & & $0 / 23$ & & \\
\hline Lung cancer & Nomoto et al. ${ }^{17}$ & 42\% (1p36LOH) & $0 / 44$ & & biallelic $(25 / 26)$ \\
\hline Lung cancer & Mai et al. ${ }^{24}$ & & $0 / 21$ & $\mathrm{~T}>\mathrm{N}(9 / 10)$ & 5 monoallelic $\mathrm{LOH}^{\mathrm{c}}+$ \\
\hline Lung cancer & Yamamoto et al. $^{\mathrm{d}}$ & $33 \%(11 / 33)$ & 1/36 (P405R) & & \\
\hline Oligodendroglioma & Mai et al. ${ }^{31}$ & & $0 / 20$ & & \\
\hline Colorectal cancer & Sunahara et al. ${ }^{25}$ & $17 \%(8 / 46)$ & $0 / 82$ & $\mathrm{~T}>\mathrm{N}$ & \\
\hline Colorectal cancer & Han et al. ${ }^{35}$ & & $0 / 43$ & & \\
\hline Esophageal cancer & Nimura et al. ${ }^{20}$ & $8 \%(2 / 25)$ & $0 / 48$ & & \\
\hline Prostate cancer & Takahashi et al. ${ }^{21}$ & $5 \%(2 / 38)$ & $0 / 106$ & $\mathrm{~T}>\mathrm{N}$ & \\
\hline Renal cell cancer & Mai et al. ${ }^{32}$ & & $0 / 27$ & $\mathrm{~T}=\mathrm{N}$ & $\begin{array}{c}\text { biallelic (all) } \\
\text { LOI }(64 \%) \\
\text { allele switching+ }\end{array}$ \\
\hline Melanoma & Kroiss et al. ${ }^{42}$ & & $0 / 17$ & & \\
\hline $\begin{array}{l}\text { Cholangiocarcinoma } \\
\text { of the liver }\end{array}$ & Tannapfel et al. ${ }^{28}$ & & & high p73 (41\%) & \\
\hline Hepatocellular cancer & Mlhara et al. ${ }^{43}$ & $20 \%(5 / 25)$ & $0 / 48$ & $\mathrm{~T}=\mathrm{N}$ & \\
\hline Breast cancer & Zaika et al. $^{26}$ & & $0 / 8$ & $\mathrm{~T}>\mathrm{N}(29 / 77)$ & $\begin{array}{c}\text { biallelic }(8 / 14) \\
\text { monoallelic }(6 / 14)\end{array}$ \\
\hline $\begin{array}{l}\text { Breast cancer } \\
\text { Breast cancer }\end{array}$ & $\begin{array}{l}\text { Shishikura et al. } \\
\text { Han et al. }\end{array}$ & $13 \%(6 / 46)$ & $\begin{array}{c}0 / 87 \\
1 / 47(\mathrm{R} 269 \mathrm{Q})\end{array}$ & $\mathrm{T}=\mathrm{N}$ & \\
\hline Brain tumor & Loiseau et al. ${ }^{45}$ & & & $\begin{array}{l}\text { Ependimoma: high } \\
\text { Others: low }\end{array}$ & \\
\hline Bladder cancer & Yokomizo et al. $^{27}$ & & $0 / 23$ & $\mathrm{~T}>\mathrm{N}(22 / 23)$ & biallelic \\
\hline Gastric cancer & Han et al. ${ }^{35}$ & & $0 / 31$ & & \\
\hline Gastric cancer & Yokozaki et al. $^{18}$ & $38 \%(12 / 32)$ & $0 / 12$ & low p73 (6/8) & biallelic (32/32) \\
\hline Ovarian cancer & Imyanitov et al. ${ }^{19}$ & $43 \%(1 \mathrm{p} 36 \mathrm{LOH})$ & & & \\
\hline
\end{tabular}

aLoss of heterozygosity; ${ }^{\mathrm{b}} \mathrm{T}$ : tumorous tissue; $\mathrm{N}$ : corresponding normal tissue; ${ }^{\mathrm{C}}$ loss of imprinting; ${ }^{\mathrm{d}}$ unpublished data 


\section{Mutations of p73 in primary cancers}

The presence of mutations or deletions in the candidate tumor suppressor gene is critical to confirm that the gene conforms to Knudson's two-hit hypothesis. ${ }^{33}$ During the last 2 years, there has been an extensive search for mutations of the p73 gene in 14 different primary cancers (Table 2). However, only four tumors with missense mutations of p73 out of 909 tumors $(0.4 \%)$ have been found. Two mutations found in primary neuroblastoma were substitutions of the proline residue (P405R and $\mathrm{P} 425 \mathrm{~L}$ ) in the $\mathrm{COOH}$-terminal region of both $\mathrm{p} 73 \alpha$ and $\mathrm{p} 73 \beta^{15}$, in which region Takada et al. ${ }^{34}$ identified a weak but significant transactivation function. P425L was a somatic mutation in neuroblastoma, while the P405R mutation was germline in a neuroblastoma and somatic in a lung cancer (N Yamamoto and A Nakagawara, unpublished data). Another somatic mutation R269Q was found in the DNAbinding domain of $\mathrm{p} 73$, although its functional significance was not examined. ${ }^{35}$ Neither truncation nor deletion types of mutation have been reported so far. Thus, unlike p53, it is obvious that $p 73$ is infrequently mutated in many human cancers. The results further suggest that p73 is not a tumor suppressor gene in a classic Knudson manner.

\section{Mutations of p51/p63 in primary cancers (Figure 9)}

Mutational analysis of p51/p63 is still limited at this time. According to the paper by Sunahara et $a .^{36}$ which expanded previous data, ${ }^{37}$ two kinds of missense mutation $(\mathrm{Q} 31 \mathrm{H}$ and $\mathrm{A} 148 \mathrm{P})$ are found in three out of 80 (3.8\%) non-small cell lung cancers. A148P was a loss of function mutation according to the yeast functional assay system (modified FASAY method). However, there was no mutation in 85 breast cancers. ${ }^{36}$ It seems likely, therefore that, like p73, p51/p63 is also rarely mutated in many human cancers.
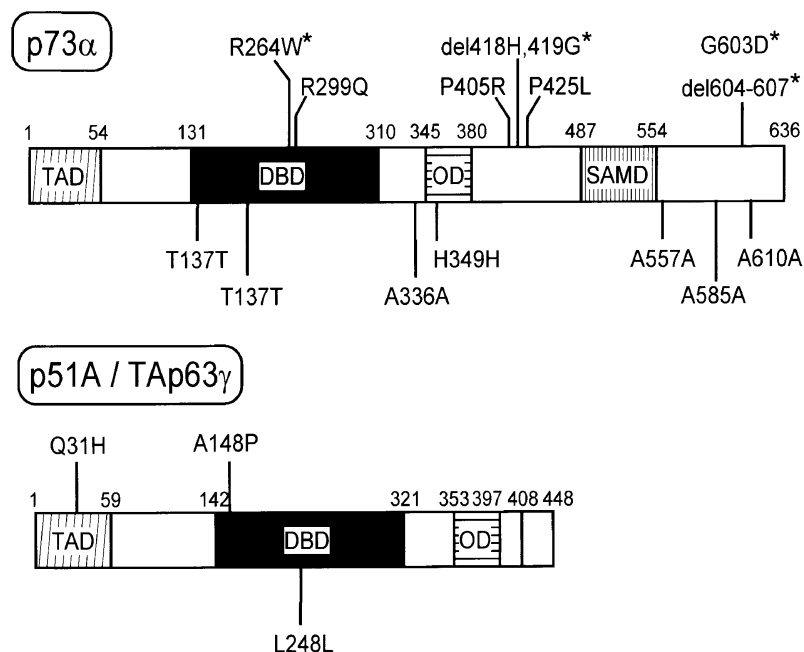

Figure 9 Missense mutations, deletions and polymorphisms of p73 $\alpha$ and p51A/TAp63 $\gamma$ found in primary cancers and cell lines. *Mutations and deletions found in cell lines. ${ }^{46,47}$ TAD: transactivation domain; DBD: DNA-binding domain; OD: oligomerization domain; SAMD: SAM domain; R: arginine; W: tryptophan; H: histidine; G: glycine; D: aspartic acid; Q: glutamine; P: proline; $\mathrm{L}$ : leucine; $\mathrm{T}$ : threonine; A: alanine; del: deletion

\section{Relationship between expression and mutation of p73 or p51/p63 and mutation of p53 in cancers}

At this point, the significant observations concerning the p73 gene in cancers are (1) a frequent $\mathrm{LOH}$ of the p73 gene in some cancers, and (2) higher levels of expression in tumors compared with those in corresponding normal tissues. In the latter, the mechanism of stimulated transcription of the p73 gene in tumors is unclear. Although overexpression of p73 in some cell lines induces apoptosis, moderate enhancement of expression in primary tumor cells may conversely increase growth. The different $\mathrm{p} 73$ splicing variants may have different growth-promoting or suppressing function, which could also vary between different tissues. Furthermore, the p73 protein may be induced by some DNA-damaging stresses without increasing the levels of the transcript. ${ }^{38}$ Thus, many factors involved in the regulation of expression and function of p73 still remain to be pursued.

The p73 protein is reported to associate with the mutant form of p53 but not with wild-type p53. ${ }^{39}$ Is there any correlation between p73 status and p53 mutations in primary cancers? In this context, Zaika et al. ${ }^{26}$ found no correlation between high expression of wild-type p73 and mutations of p53 in 12 primary breast cancers. However, in a larger analysis in a wider range of cancers, the two were significantly associated ( $T$ Shishikura and $A$ Nakagawara, submitted for publication). In this case, mutated p53 may inhibit the function of overexpressed, p73 leading the tumor cells into a more aggressive phenotype. Interestingly, a non-small cell lung cancer with a mutation of p73 (P405R) also had a p53 mutation in the DNA-binding domain, and the patient had multiple metastasis ( $\mathrm{N}$ Yamamoto et al. unpublished data). A mutation of p51/p63 (A148P) has also been associated with a p53 mutation, and this tumor was also in an advanced stage. ${ }^{26}$ Since the p53 family molecules are inducible in cancers by some stresses such as DNA damage at the mRNA or protein levels, the status of their expression and mutation may affect the clinical behavior of the tumor during therapy.

\section{Distinct functional role of the COOH-terminal region of p73 and p51/p63}

Unlike p53, both p73 and p51/p63 have an additional $\mathrm{COOH}-$ terminal region which is variably spliced. Two naturally occurring missense mutations have been found in the $\mathrm{COOH}$-terminal region of p73 in neuroblastomas and lung cancer. ${ }^{15}$ In addition, this region of both p73 and p51/p63 contains the SAM-like domain which may be involved in protein-protein interactions. ${ }^{40}$ These data suggest that the $\mathrm{COOH}$-terminal region of $\mathrm{p} 73$ and $\mathrm{p} 51 / \mathrm{p} 63$ has a distinct function which is not shown by $\mathrm{p} 53$.

Takada et al. $^{34}$ found that the region of amino acid residues $382-491$ of $p 73 \alpha$ or $p 73 \beta$ was rich in glutamine and proline, in which two naturally occurring mutations, P405R and P425L, were present. By using the yeast GAL4 DNA-binding fusion system, they found a weak, but significant transactivation activity in the region, and both mutations resulted in loss of this activity. Though the 
physiological significance of this region is still unclear, further functional analysis should be rewarding.

The SAM-like domain of p73 or p51/p63 may have an important role in regulating oligomerization as well as other functions. ${ }^{40}$ Ozaki et al. ${ }^{48}$ found that the $\mathrm{COOH}$-terminal region of $p 73 \alpha$ distal to the SAM-like domain is also a functional regulatory domain which both affects transcriptional activation and colony forming activity. ${ }^{41}$ Their results showed that the $p 73 \alpha$ truncation mutant with deletion of the most $\mathrm{COOH}$-terminal region including a SAM domain, or with deletion of the extreme $\mathrm{COOH}$-terminal distal to a SAM domain increased the transcription of luciferase reporters harboring three p53-responsive promoters (p21Waf1, Mdm2, and Bax) in p53-deficient SAOS-2 cells. On the other hand, induction of apoptosis tested by the colony formation assay was strongly inhibited by transfection of these deletion mutants in the same cells. In addition, it appears that the distal $\mathrm{COOH}$-terminal region of $\mathrm{p73} \alpha$ is a cis- or trans-acting regulatory domain which regulates its functions in a diverse manner.

\section{Acknowledgments}

The authors are grateful for Drs I Katoh, M Osada, and K Aisaki, and Ms Y Miyata for their help in organizing the manuscript.

\section{References}

1. Kaghad M, Bonnet H, Yang A, Creancier L, Biscan JC, Valent A, Minty A, Chalon P, Lelias JM, Dumont X, Ferrara P, McKeon F and CaputD (1997) Monoallelically expressed gene related to $\mathrm{p} 53$ at $1 \mathrm{p} 36$, a region frequently deleted in neuroblastoma and other human cancers. Cell 90: 809-819.

2. Osada M, Ohba M, Kawahara C, Ishioka C, Kanamaru R, Katoh I, Ikawa Y, Nimura Y, Nakagawara A, Obinata M and lkawa S (1998) Cloning and functional analysis of human $p 51$, which structurally and functionally resembles $p 53$. Nature Medicine 4: 839-843.

3. Schmale $\mathrm{H}$ and Bambergeric $\mathrm{C}$ (1997) A novel protein with strong homology to the tumor suppressor p53. Oncogene 15: 1363-1367.

4. Trink B, Okami K, Wu L, Spiuranpong V, Jen J and Sidransky D (1998) A new human 553 homolog. Nature Medicine 4: 747-748.

5. Yang A, Kaghad M, Wang Y, GillettE, Fleming MD, Dotsch V, Andrews NC, Caput $D$ and McKeon $F$ (1998) p63, a p53 homolog at 3q27-29, encodes multiple products with transactivating, death-inducing, and dominant-negative activities. Mol. Cell 2: 305-316.

6. Senoo M, Seiki N, Ohira M, Sugano S, Watanabe M, Tachibana M, Tanaka T, Shinkai $Y$ and Kato $\mathrm{H}$ (1998) A second p53-related protein, p7L, with high homology to p73. Biochem. Biophys. Res. Commun. 248: 603-607.

7. De Laurenzi V, Constanzo A, Barcaroli D, Terrinoni A, Falco M, AnnicchaiaricoPetruzzelli M, Levrero M and Melino G (1998) Two new p73 splice variants, g and d, with different transcriptional activity. J. Exp. Med. 188: 1763-1768.

8. Tani M, Shimizu K, Kawahara C, Kohno T, Ishimoto O, Ikawa S and Yokota J (1999) Mutation and expression of the p51 gene in human lung cancer. Neoplasia 1: $71-79$

9. Mills AA, Zheng B, Wang XJ, Vogel H, Roop DR, and Bradley A (1999) p63 is a homologue required for limb and epidermal morphogenesis. Nature 398: 708 713.

10. Yang A, Schweitzer R, Sun D, Kaghad M, Walker N, Bronson RT, Tabin C, Sharpe A, Caput D, Crum C and McKeon F (1999) p63 is essential for regenerative proliferation in limb, craniofacial and epithelial development. Nature 398: 714-718.

11. Suda Y, Aizawa S, Furuta Y, Yagi T, Ikawa Y, Saitoh K, Yamada Y, Toyoshima K and Yamamoto $Y(1990)$ Induction of a variety of tumors by c-erbB2 and clonal nature of lymphomas even with the mutated gene (Val659-Glu659). EMBO J. 9 : $181-190$.
12. Xu X, Yamamura Y, Tsukada T, Yoshida MA, Senda H, Nagayoshi M, Ikeuchi T and lkawa Y (1995) A mouse erythroleukemia cell line possessing Friend spleen focus-forming virus gp55 transgene and temperature-sensitive mutant p53 gene. Jpn. J. Cancer Res. 86: 284-291.

13. Lo Cunsolo C, Casciano I, Banelli B, Tonini GP and Romani M (1998) Refined chromosomal localization of the putative tumor suppressor gene TP73. Cytogenet. Cell Genet. 82: 199-201.

14. Perri P, Prami C, Savelyeva L, Pillmann A and Schwab M (1999) Fine mapping of distal 1p loci reveals TP73 at D1S468. Cytogenet. Cell Genet. 84: 111-114.

15. Ichimiya S, Nimura $Y$, Kageyama $H$, Takada N, Sunahara M, Shishikura $T$, Nakamura Y, Sakiyama S, Seki N, Ohira M, Kaneko Y, McKeon F, Caput D and Nakagawara A (1999) p73 at chromosome 1 p36.3 is lost in advanced stage neuroblastoma but its mutation is infrequent. Oncogene 18: 1061-1066.

16. Ejeskar K, Sjoberg R-M, Kogner P and Martinsson T (1999) Variable expression and absence of mutations in p73 in primary neuroblastoma tumors argues against a role in neuroblastoma development. Int. J. Mol. Med. 3: 585-589.

17. Nomoto S, Haruki N, Kondo M, Konishi H, Takahashi T, Takahashi T and Takahashi T (1998) Search for mutations and examination of allelic expression imbalance of the p73 gene at 1 p36.33 in human lung cancers. Cancer Res. 58: $1380-1383$.

18. Yokozaki H, Shitara Y, Fujimoto JY, Hiyama T, Yasui W and Tahara E (1999) Alterations of $p 73$ preferentially occur in gastric adenocarcinomas with foveolar epithelial phenotype. Int. J. Cancer 83: 192-196.

19. Imyanitov EN, Birrell GW, Filippovich I, Sorokina N, Arnold J, Mould MA, Wright K, Walsh M, Mok SC, Lavin MF, Chenevix-Trench G and Khanna KK (1999) Frequent loss of heterozygosity at $1 \mathrm{p} 36$ in ovarian adenocarcinomas but the gene encoding p73 is unlikely to be the target. Oncogene 18: 4640-4642.

20. Nimura $Y$, Mihara M, Ichimiya S, Sakiyama S, Seki N, Ohira M, Nomura N, Fujimori M, Adachi W, Amano J, He M, Ping Y-M and Nakagawara A (1998) p73, a gene related to $p 53$, is not mutated in esophageal carcinomas. Int. J. Cancer 78 : 437-440.

21. Takahashi H, Ichimiya S, Nimura Y, Watanabe M, Furusato M, Wakui S, Yatani R, Aizawa S and Nakagawara A (1998) Mutation, Allelotyping, and transcription analyses of the p73 gene in prostatic carcinoma. Cancer Res. 58: 2076-2077.

22. De Laurenzi V, Catani MV, Terrinoni A, Corazzari M, Melino G, Costanzo A, Levrero M and Knight RA (1999) Additional complexity in p73: induction by mitogens in lymphoid cells and identification of two new splicing variants e and $z$. Cell Death Differ. 6: 389-390.

23. Kovalev S, Marchenko N, Swendeman S, LaQuaglia M and Moll UM (1998) Expression level, allelic origin, and mutation analysis of the $p 73$ gene in neuroblastoma tumors and cell lines. Cell Growth Diff. 9: 897-903.

24. Mai M, Yokomizo A, Qian C, Yang P, Tindall DJ, Smith DI and Liu W (1998) Activation of $p 73$ silent allele in lung cancer. Cancer Res. 58: 2347-2349.

25. Sunahara M, Ichimiya S, Nuimura Y, Takada N, Sakiyama S, Sato Y, Todo S, Adachi W, Amano J and Nakagawara A (1998) Mutational analysis of the p73 gene localized at chromosome $1 \mathrm{p} 36.3$ in colorectal carcinomas. Int. J. Oncol. 13: 319-323.

26. Zaika AI, Kovalev S, Marchenko D and Moll UM (1999) Overexpression of the wild type p73 gene in breast cancertissues and cell lines. Cancer Res. 59:32573263.

27. Yokomizo A, Mai M, Tindall DJ, Cheng L, BostwickD, Naito S, Smith DI and Liu W (1999) Overexpression of the wild type p73 gene in human bladder cancer. Oncogene 18: 1629-1633.

28. Tannapfel A, Engeland K, Weinans L, Katalinic A, Hauss J, Mossner J and Wittekind $\mathrm{CH}$ (1999) Expression of $\mathrm{p} 73$, a novel protein related to the p53 tumour suppressor p53, and apoptosis in cholangiocellular carcinoma of the liver. Br. J. Cancer 80: 1069-1074.

29. Caron $\mathrm{H}$, van Sluis $\mathrm{P}$, van Hoeve M, de Kraker J, Bras J, Slater R, Mannens M, Voute PA, Westerveld A and Versteeg R (1993) Allelic loss of chromosome $1 \mathrm{p} 36$ in neuroblastoma is of preferential maternal origin and correlates with $\mathrm{N}$-myc amplification. Nat. Genet. 4: 187-190.

30. Caron H, Peter M, van Sluis P, Speleman F, de Kraker J, Laureys G, Michon J, Brugieres L, Voute PA, Westerveld A, Slater R, Delattre O and Versteeg R(1995) Evidence for two tumour suppressor loci on chromosomal bands 1p35-36 involved in neuroblastoma: one probably imprinted, another associated with $\mathrm{N}$ myc amplification. Hum. Mol. Genet. 4: 535-539.

31. Mai M, Huang H, Reed C, Qian C, smith JS, Alderete B, Jenkins R, Smith DI and Liu W (1998) Genomic organization and mutation analysis of p73 in oligodendrogliomas with chromosome 1 p-Arm deletion. Genomics 51: 359 363. 
32. Mai M, Qian C, Yokomizo A, Tindall DJ, Bostwick D, Polychronakos C, Smith DI and Liu W (1998) Loss of imprinting and allele switching of p73 in renal cell carcinoma. Oncogene 17: 1739-1741.

33. Knudson AG (1971) Mutation and cancer: statistical study of retinoblastoma. Proc. Natl. Acad. Sci. USA 68: 820-823.

34. Takada N, Ozaki T, Ichimiya S, Todo S and Nakagawara A (1999) Identification of a transactivation activity in the $\mathrm{COOH}$-terminal region of $\mathrm{p} 73$ which is impaired in the naturally occurring mutants found in human neuroblastomas. Cancer Res. 59: $2810-2814$.

35. Han S, Semba S, Abe T, Makino N, Furukawa T, Fukushige S, Takahashi $H$, Sakurada A, Sato M, Shiiba K, Matsuno S, Nimura Y, Nakagawara A and Horii A (1999) Infrequent somatic mutations of the p73 gene in various human cancers. Eur. J. Surg. Oncol. 25: 194-198.

36. Sunahara M, Shishikura T, Takahashi M, Todo S, Yamamoto N, Kimura H, Kato S, Ishioka C, Ikawa S, Ikawa Y and Nakagawara A (1999) Mutational analysis of p51A/TAp63 $\gamma$, a p53 homolog, in non-small cell lung cancer and breast cancer. Oncogene 18: $3761-3765$.

37. Osada M, Ohba M, Kawahara C, Ishioka C, Kanamaru R, Katoh I, Ikawa Y, Nimura Y, Nakagawara A, Obinata M and Ikawa S (1999) Cloning and functional analysis of human $\mathrm{p} 51$, which structurally and functionally resembles $\mathrm{p} 53$. Nat. Med. 4: 839-843.

38. Gong JG, Costanzo A, Yang HQ, Melino G, Kaelin WG Jr, Levrero M and Wang JY (1999) The tyrosine kinase c-Ab1 regulates p73 in apoptotic response to cisplatin-induced DNA damage. Nature 399: 806-809.

39. Di Como CJ, Gaiddon C and Prives C (1999) p73 function is inhibited by tumorderived p53 mutants in mammalian cells. Mol. Cell. Biol. 19: 1438-1449.

40. Chi SW, Ayed A and Arrowsmith $\mathrm{CH}$ (1999) Solution structure of a conserved Cterminal domain of $p 73$ with structural homology to the SAM domain. EMBOJ. 18: $4438-4445$.
41. Yokomizo A, Mai M, BostwickDG, Tindall DJ, Qian J, Cheng L, Jenkins RB, Smith DI and Liu W (1999) Mutation and expression analysis of the 73 gene in prostate cancer. The Prostate 39: 94-100.

42. Kroiss MM, Bosserhoff A-K, Vogt T, BuettnerR, Bogenrieder T, Landthaler Mand Stolz W (1998) Loss of expression or mutations in the p73 tumour suppressor gene are not involved in the pathogenesis of malignant malanomas. Melanoma Res. 8: 504-509.

43. Mihara M, Nimura Y, Ichimiya S, Sakiyama S, Kajikawa S, Adachi W, Amano J and Nakagawara A (1999) Absence of mutation of the p73 gene localized a chromosome 1p36.3 in hepatocellular carcinoma. Br. J. Cancer 79: 164-167.

44. Shishikura $T$, Ichimiya S, Ozaki T, Nimura $Y$, Kageyama $H$, Nakamura $Y$, Sakiyama S, Miyauchi M, Yamamoto N, Suzuki M, Nakajima N and Nakagawara A (1999) Mutational analysis of the p73 gene in human breast cancers. Int. J. Cancer 84: $321-325$

45. Loiseau $\mathrm{H}$, Arsaut $\mathrm{J}$ and Demotes-Mainard $\mathrm{J}$ (1999) p73 gene transcripts in human brain tumors: overexpression and altered splicing in ependymomas.

46. Yoshikawa H, Nagashima M, Khan MA, McMenamin MG, Hagiwara Kand Harris CC (1999) Mutational analysis of p73 and p53 in human cancer cell lines. Oncogene 18: 3415-3421.

47. Tsao H, Zhang X, Majewski $P$ and Haluska FG (1999) Mutational and expression analysis of the p73 gene in melanoma cell lines. Cancer Res. 59: 172-174.

48. Ozaki T, Naka M, Takada N, Tada M, Sakiyama S and Nakagawara A (1999) Deletion of the $\mathrm{COOH}$-terminal region of $\mathrm{p} 73 \mathrm{a}$ enchances both its transactivation function and DNA-binding activity but inhibits induction of apoptosis in mammalian cells. Cancer Res. in press. 